\title{
Kebijakan Pengaturan Penggunaan Dana Bagi Hasil Cukai Hasil Tembakau Dalam Program Pembinaan Lingkungan Sosial Guna Pengentasan Kemiskinan
}

\author{
Suteki, Nastiti Rahajeng Putri \\ Fakultas Hukum, Universitas Diponegoro \\ Jalan Prof. Soedarto, S.H., Tembalang, Semarang \\ Email: nastiti@lecturer.undip.ac.id
}

\begin{abstract}
The aim of this research is to find out how the regulation policy (formulation) of the use of the allocation of funds for tobacco excise revenue sharing (DBHCHT) is related to the social environmental development program. The results showed that the regulatory policy (formulation) on poverty alleviation through DBHCHT management in each region was different. This can lead to optimal management of DBHCHT because it is strong enough to involve all stakeholders in poverty alleviation while still relying on how the work of SKPD-SKPD, community and private sector to be actively involved. The role of the DBHCHT management policy formulation in poverty alleviation programs can actually be said to have a qualitatively significant role proven to be able to direct local government through empowering SKPDs to jointly implement poverty alleviation programs.
\end{abstract}

Keywords: Law, Means of poverty alleviation, DBHCHT

\begin{abstract}
Abstrak
Penelitian bertujuan utnuk mengetahui bagaimanakah kebijakan pengaturan (formulasi) penggunaan alokasi dana bagi hasil cukai hasil tembakau (DBHCHT) terkait dengan program pembinaan lingkungan sosial. Hasil penelitian menunjukkan bahwa kebijakan pengaturan (formulasi) tentang pengentasan kemiskinan melalui pengelolaan DBHCHT pada masing-masing daerah berbeda-beda. Hal ini dapat menyebabkan pengelolaan DBHCHT cukup optimal karena cukup kuat untuk melibatkan seluruh stakeholders dalam pengentasan kemiskinan meskipun tetap mengandalkan bagaimana kiprah SKPD-SKPD, masyarakat dan swasta untuk terlibat secara aktif. Peran formulasi kebijakan pengelolaan DBHCHT dalam program pengentasan kemiskinan sebenarnya dapat dikatakan memiliki peran yang secara kualitatif signifikan terbukti mampu mengarahkan pemeritnah setempat melalui pemberdayaan SKPD-SKPD untuk secara bersama-sama melaksanakan program pengentasan kemiskinan.
\end{abstract}

Kata kunci: Hukum, Sarana pengentasan kemiskinan, DBHCHT. 


\section{A. Pendahuluan.}

Hukum itu bukan merupakan tujuan, akan tetapi hanya merupakan jembatan, yang akan harus membawa kita kepada ide yang dicita-citakan. Untuk itu kita harus mengetahui masyarakat yang bagaimana yang dicita-citakan oleh bangsa Indonesia baru kemudian kita dapat menentukan hukum yang bagaimana yang dapat membawa rakyat kita ke arah masyarakat yang dicita-citakan itu. Cita-cita bangsa Indonesia tidak lain adalah tujuan nasional yang tercantum dalam alinea ke-4 Pembukaan UUD 1945. Tujuan nasional tersebut adalah (1) melindungi segenap bangsa Indonesia dan seluruh tumpah darah Indonesia, (2) memajukan kesejahteraan umum, (3) mencerdaskan kehidupan bangsa dan (4) ikut melaksanakan ketertiban dunia yang berdasarkan kemerdekaan, perdamaian abadi dan keadilan sosial.

Sebagai negara hukum ${ }^{1}$, negara Indonesia dapat mendayagunakan hukum sebagai sarana untuk mewujudkan cita-cita nasional atau dalam bahasa kebijakan, hukum dapat digunakan sebagai instrumen kebijakan tertentu (law as an instrument of policy). Memajukan kesejahteraan umum (sosial) merupakan salah satu tujuan negara hukum Indonesia didirikan. Tujuan nasional ini seharusnya diterjemahkan ke dalam instrumen peraturan perundang-undangan di bawah UUD 1945. Hukum dalam wajahnya berupa sistem peraturan perundang-undangan inilah yang diharapkan mampu mewujudkan kesejahteraan umum (sosial). Untuk dapat mewujudkan kesejahteraan sosial, maka hukum harus dapat menciptakan keadilan, bukan hanya keadilan individual (baik keadilan legal, maupun keadilan komutatif), melainkan juga keadilan distributif atau dapat diterjemahkan lebih kongkret menjadi keadilan sosial.

Berdasarkan uraian di atas tampak jelas bahwa hukum dan keadilan sosial memiliki hubungan yang sangat erat dengan kesejahteraan sosial. Dalam UUD 1945, Kesejahteraan Sosial diatur dalam Pasal 33 dan 34. Dapat dikatakan bahwa kesejahteraan sosial menyangkut pemenuhan kebutuhan materiil yang harus diatur dalam organisasi dan

\footnotetext{
${ }^{1}$ Jimly Assiddiqie memerinci karaktristik negara hukum dengan menyebut 12 ciri. Karakteristik tersebut yaitu: (1) Supremasi hukum (Supremacy of Law); (2) Persamaan dalam Hukum (Equality before the Law); (3) Asas legalitas (Due Process of Law); (4) Pembatasan kekuasaan; (5) Organ-organ Eksekutif Independen; (6) Peradilan Bebas dan Tidak Memihak; (7) Adanya Peradilan Tata Usaha Negara; (8) Peradilan Tata Negara (Constitutional Court); (9) Perlindungan Hak Asasi Manusia; (10) Bersifat Demokratis (Demecratische Rechtsstaat); (11) Berfungsi Sebagai Sarana Untuk Mewujudkan Tujuan Negera (Welfare Rechtsstaat) dan (12) Transparansi dan Kontrol Sosial. Lihat, Jimly Asshiddiqie, Konstitusi dan Konstitusionalisme Indonesia, Sekretariat Jenderal dan Kepaniteraan Mahkamah Konstitusi, Jakarta, 2006, hlm. 151-161.
} 
sistem ekonomi yang berdasarkan kekeluargaan. Kesejahteraan sosial adalah sarana materiil yang harus dipenenuhi untuk mencapai rasa aman dan tenteram yang disebut keadilan sosial. Sedangkan keadilan sosial merupakan tujuan yang lebih tinggi daripada sekedar kesejahteraan. Keadilan merupakan condition sine qua non terciptanya ketertiban dan merupakan syarat utama berlangsungnya kehidupan masyarakat. Keadilan menjaga supaya tidak terjadi ketimpangan sehingga tercipta keseimbangan antara hak dan kewajiban, adanya keseimbangan antara kepentingan pribadi dan kepentingan sosial.

Melalui UU No. 39 Tahun 2007 tentang Cukai, negara sebenarnya ingin agar pelaksanaan UU ini juga dapat menciptakan kesejahteraan sosial. Hal ini dapat dibuktikan melalui isi dari konsiderans UU Cukai tersebut. UU Cukai disusun berdasarkan pertimbangan bahwa cukai sebagai pungutan negara yang dikenakan terhadap barangbarang tertentu yang mempunyai sifat atau karakteristik sesuai dengan undang-undang merupakan penerimaan negara guna mewujudkan kesejahteraan bangsa. Kesejahteraan bangsa menjadi tanggung jawab negara c.q. pemerintah, baik pemerintah pusat maupun pemerintah daerah. Instrumen otonomi daerah berusaha membagi tanggung jawab terhadap kewajiban untuk mewujudkan kesejahteraan rakyat oleh pemerintah pusat dengan pemerintah daerah. Salah satu cara untuk mendanai pembangunan di daerah adalah alokasi pendanaan dari pemerintah pusat yang diberikan kepada pemerintah daerah dalam bentuk Dana Alokasi Umum (DAU). Pengalokasian dana bagi hasil tembakau yang diatur dalam UU Cukai merupakan salah satu cara pemerintah pusat mendanai pembangunan di daerah melalui DAU untuk mewujudkan kesejahteraan sosial. Pasal 66A secara tegas menyatakan bahwa salah satu cara penggunaan alokasi DBHCHT adalah untuk melakukan pembinaan lingkungan sosial, maka berarti persoalan penaggulangan kemiskinan dapat menjadi salah satu sasaran program tersebut. Dalam hal ini hukum, melalui peraturan perundang-undang sedang menjalani fungsinya sebagai sarana untuk melakukan rekayasa sosial (law as a tool of social engineering).

Pada awal digulirkan alokasi dana DBHCHT, praktik penggunaan dana alokasi bagi hasil tembakau di beberapa daerah ditemukan beberapa variasi. Seperti yang dilaporkan oleh Tim Humas Provinsi Jawa Tengah, pengelolaan Dana Bagi Hasil cukai rokok untuk Jawa Tengah belum optimal, dari 52,196 M baru sekitar $3 \mathrm{M}$ yang digunakan untuk peningkatan usaha pertanian. Pada tahun 2008 total alokasi Cukai hasil tembakau yang dikembalikan ke Provinsi dan kabupaten/kota sebesar 52,196 M, dengan perincian Kabupaten Kudus mendapatkan 17,2 M, provinsi 15,6 M, Kota Surakarta 1,2 M dan 
seluruh Kabupatenkota yang besarnya antara 450 juta sampai 878 juta. Pada tahun 2009 kenaikan DBHCT untuk Jawa Tengah mengalami kenaikan yang dramatis, dari Rp 52 milyar pada tahun 2008 menjadi Rp 282 milyar untuk tahun 2009. Pembagian dana sebesar Rp 282 milyar tersebut adalah 30 \% (84,6 milyar) untuk Pemerintah Provinsi Jawa Tengah, dan $70 \%$ (197,4 milyar) sisanya dibagikan ke pada 35 Kabupaten/Kota secara proporsional. Sebesar 40\% dari 197,4 milyar diberikan kepada 15 Kabupaten/Kota penghasil tembakau, 30\% lainnya diberikan kepada 35 kabupaten/kota secara merata.

Menurut Wakil ketua komisi B DPRD Jawa Tengah Muhammad Haris alokasi penggunaan dana bagi hasil cukai untuk pemerintah provinsi belum diarahkan pada upaya peningkatan produktifitas pertanian dan UMKM. Dari 15,6 M yang digunakan untuk mendorong potensi usaha kecil hanya kurang dari $3 \mathrm{M}$, selainya digunakan untuk kegiatan lain. Dalam Perubahan APBD 2008 hanya ada beberapa kegiatan yang berdampak langsung pada masyarkat misalnya pengembangan diversifikasi usaha dan sistem distribusi koperasi dan UMKM sebesar 845 juta, pengembangan SDM dan kelembagaan koperasi dan UMKM 714 juta. Masih banyak kegiatan yang terkesan untuk menghabiskan uang saja misalnya promosi bahaya rokok lewat komik, DVD, serta sarana-sarana lain yang sebenarnya tidak sesuai peruntukan dan tidak diperlukan masyarakat. Haris berharap adanya transparansi dari pemerintah provinsi tentang penggunaan alokasi bagi hasil cukai tembakau ini. Karena masih baru, maka perlu transparansi dan harus benar-benar manfaat jangan hanya yang penting habis.

Delapan tahun kemudian, yakni sejak tahun 2016 penggunaan DBHCHT semakin bervariasi dan diarahkan untuk kegiatan-kegiatan produktif pada beberapa SKPD sehingga DBHCHT dapat dinikmati oleh seluruh lapisan masyarakat. Penggunaan DBHCHT tidak hanya ditekankan pada penguatan ekonomi rakyat melainkan juga untuk mendanai keperluan kesehatan, bahkan hingga tahun 2018 ini alokasi untuk dana kesehatan sebanyak 50 persen dari total DBHCHT yang diterima oleh masing-masing daerah. Lebih tepat lagi dana sebesar 50 persen tersebut untuk alokasi pembiayaan Jaminan Kesehatan Nasional. Namun demikian, program penguatan ekonomi dalam rangka pengentasan kemiskinan tetap berjalan.

Situasi dilematis akan dihadapi oleh pemerintah sebagai penyelenggara negara yang bertanggung jawab terhadap kesejahteraan rakyatnya. Di satu sisi, cukai rokok mempunyai posisi strategis untuk menyokong APBN (termasuk APBD) khususnya dapat digunakan untuk melakukan pembinaan lingkungan sosial (misalnya program pengentasan 
kemiskinan), di sisi lain dampak akibat rokok perlu diKudusikan. Dewasa ini kampanye anti rokok serta adanya peraturan di tingkat daerah yang membatasi masyarakat untuk merokok jelas merupakan upaya untuk mengendalikan dampak rokok bagi kesehatan masyarakat. Kesadaran terhadap bahaya rokok terus ditingkatkan namun harapan perolehan "uang" dari sistem industri rokok tetap pula didambakan oleh jutaan penduduk, termasuk oleh Pemda (APBD) di daerah produsen rokok dan tembakau. Keadaan demikian sering menggiring pada statemen yang menyatakan bahwa cukai rokok itu adalah "tax of sin”. Dengan demikian penelitian ini bertujuan untuk mengetahui Bagaimanakah kebijakan pengaturan (formulasi) penggunaan alokasi Dana Bagi Hasil Cukai Hasil Tembakau (DBHCHT) terkait dengan program pembinaan lingkungan sosial?

\section{Konsep Fungsi Hukum}

Hoebel berpendapat bahwa ada empat fungsi dasar hukum yaitu :

a. Menetapkan hubungan-hubungan antar anggota masyarakat, dengan menunjukan jenis-jenis tingkah laku apa yang diperkenankan dan apa pula yang dilaranga;

b. Menentukan pembegian kekuasaan dan mencari siapa saja yang boleh melakukan paksaaan serta siapakah yang harus menaatinya dan sekaligus memilih sanksi-sanksinya yang tepat dan efektif;

c. Menyelesaikan sengketa;

d. Memelihara kemampuan masyarakat untuk menyesuaikan diri dengan keadaan kehidupan yang berubah-ubah, yaitu dengan merumuskan kembali hubungan yang esensial antara anggota-anggota masyarakat. ${ }^{2}$

Menuerut Profesor Peters, terdapat tiga perspektif dari fungsi hukum didalam masyarakat, yaitu : Perspektif pertama adalah perspektif kontrol sosial (social control). Tinjauan yang demikian ini dapat disebut sebagai tinjauan dari sudut pandang seseorang polisi terhadap hukum (the policeman view the law).

Perspektif kedua dari fungsi hukum didalam masyarakat adalah perspektif social engineering yang merupakan tinjauan yang dipergunakan para pejabat (the official perspektif of the law) dan oleh karena pusat perhatiaanya adalah apa yang diperbuat pejabat atau penguasa maka tinjauan ini kerpakali disebut sebagai the technocrat's view of the law.

\footnotetext{
${ }^{2}$ Warassih, Esmi, "Peranan Hukum dan Fungsi-fumngsinya", Masalah -masalah Hukum, No.5 - 1991, hlm. 6.
} 
a. Perspektif ketiga adalah perspektif emansipasi masyarakat dari hukum. Perspektif ini merupakan tinjauan dari bawah terhadap hukum (the bottom's up view the law). Dengan perspektif ini ditinjau kemungkinan-kemungkinan dan kemampuan hukum sebagai sarana untuk menampung semua aspirasi masyarakat. ${ }^{3}$

b. Sesuai dengan tujan penelitian ini, maka yang perlu unutk dijelaskan adalah fungsi hukum dalam perspektif social engineering atau penggunaan hukum sebagai sarana untuk mengubah masyarakat. Salah satu fungsi hukum adalah sebagai alat untuk mengubah masyarakat, dalam arti bahwa hukum sangat mungkin digunakan sebagai alat oleh pelopor perubah (agent of change). Agent of change atau pelopor perubahan adalah seorang atau kelompok orang yang mendapat kepercayaan dari masyarakar untuk memimpin satu atau lebih lembaga-lembaga kemasyarakatan. Pelopor perubahan memimpin masyarakat dalam mengubah sistem sosial dan dalam menjalankan hal itu langsung tersangkut dengan tekanan-tekanan untuk melakukan perubahan. Setiap perubahan sosial yang dikehendaki atau yang direncanakan, selalu berada di bawah pengendalian serta pengawasan pelopor perubahan tersebut. Oleh karena itu cara-cara untuk mempengaruhi masyarakat dengan sistem-sistem yang direncanakan dan diatur lebih dahulu dinamakan social engineering atau social planning. $^{4}$

Kaidah-kaidah hukum sebagai alat untuk mengubah masyarakat mempunyai peranan penting terutama dalam perubahan-perubahan yang direncanakan (intended change atau planed change). Dengan perubahan yang dikehendaki dan direncanakan tersebut, dimaksudkan sebagai suatu perubahan yang dikehendaki dan direncanakan oleh warga-warga masyarakat yang berperan sebagai pelopor masyarakat. Dalam masyarakat-masyarakat yang sudah kompleks dimana birokrasi memegang peranan penting dalam tindakan-tindakan sosial, perubahan-perubahan tersebut harus mempinyai dasar hukum untuk sahnya. Legalitas dari perubahan tersebut sangat penting artinya. Kaidah-kaidah hukum yang telah terbentuk, dapamerupakan alat yang ampuh untuk mengadakan perubahan-perubahan sosial, walaupun secara tidak langsung. Dengan demikan apabila pemerintah ingin membentuk badan-badan yang berfungsi

\footnotetext{
${ }^{3}$ Soemitro, Ronny H, Studi Hukum dan Masyarakat, (Bandung, Alumni, 1985), hlm. 10-11.

${ }^{4}$ Soekanto, Soerjono, Pokok-pokok Sosiologi Hukum, (jakarta : Rajawali, 1986), hlm. 107.
}

Administrative Law \& Governance Journal. Volume 3 Issue 1, March 2020 
Administrative Law \& Governance Journal. Volume 3 Issue 1, March 2020 ISSN. 2621-2781 Online

untuk mengubah masyarakat secara terencana, maka hukum diperlukan untuk membentuk badan tersebut serta untuk menentukan dan membatasi kekuasaannya. Sampai di sini sudah terungkap bahwa kaidah hukum dapat mendorong terjadinya perubahan-perubahan sosial yang membentuk badan-badan yang secara langsung berpengaruh terhadap perkembangan di bidang sosial, politik, bahkan di bidang ekonomi. $^{5}$

Dalam hal penggunaan hukum sebagai alat untuk mengubah masyarakat, maka hukum tersebut harus disesuaikan dengan anggapan-anggapan masyarakat apabila suatu hasil positif hendak dicapai. Dengan pernyataan ini maka yang perlu dilakukan pertama adalah menelaah bagaimana anggapan-anggapan masyarakat tentang hukum. Artinya, apakah pada suatu saat fokus masyarakat tertuju pada hukum atau tidak. Kedua, perlu disoroti bagian-bagian manakah dari suatu sistem yang paling dihargai oleh sebagian terbesar masyarakat pada suatu saat. Hal-hal inilah secara minimal harus dipertimbangkan. ${ }^{6}$

Di samping ada beberapa hal yang perlu diperhatikan, yaitu anggapan masyarakat terhadap hukum dan bagian yang paling mendapat penghargaan masyarakat, terdapat beberapa kondisi yang harus mendasari suatu sistem hukum agar dapat dipakai sebagai alat untuk mengubah masyarakat (a tool of socisl enginering). Kondisi-kondisi tersebut adalah: 1). Hukum merupakan aturan-aturan umum yang tetap; jadi bukan merupakan aturan yang bersifat ad hoc; 2). Hukum tersebut harus jelas bagi dan diketahui oleh warga-warga masyarakat yang kepentingannya diatur oleh hukum tersebut; 3). Sebaiknya dihindari penerapan peraturan-peraturan yang bersifat retroaktif; 4). Hukum tersebut harus dimengerti oleh umum; 5) Tidak ada peraturanperaturan yang bertentangan; 6). Pembentukan hukum harus memperhatiakan kemampuan para warga masyarakat untuk mematuhi hukum tersebut; 7). Perlu dihindarkan terlalu banyaknya, perubahan-perubahan hukum, oleh karena warga-warga masyarakat dapat kehilangan ukuran dan pegangan bagi kegiatannya; 8). Adanya korelasi antara hukum dengan pelaksanaan atau penerapan hukum tersebut. ${ }^{7}$

Pada kebanyakan masyarakat sistem hukumnya banyak berpengaruh dan mendukung lembaga-lembaga sosial yang telah ada. Suatu pemerintah yang berkuasa

\footnotetext{
${ }^{5}$ Ibid, hlm. 110-111.

${ }^{6}$ Ibid, hlm. 116.

${ }^{7}$ Ibid, hlm. 130.
}

Administrative Law \& Governance Journal. Volume 3 Issue 1, March 2020 
dapat menggunakan hukum untuk merubah lembaga-lembaga sosial yang berupa polapola tingkah laku yang telah ada. Perubahan lembaga-lembaga yang berupa pola-pola tingkah laku tersebut diharapkan hukum sampai sampai tingkatan tertentu mampu mengarahkan tingkah laku tersebut hingga dapat berfungsi sebagai sarana untuk menghapuskan atau mengurangi kemiskinan. Hal ini tergantung dari dua faktor yaitu: pertama, penguasa harus berkemauan keras untuk mengadakan perubahan-perubahan dan kedua, perbahan-perubahan itu hanya dapat terjadi bila tidak terdapat perbedaan pendapat antara para penguasa politik dengan kelompok pengendali ekonomi termasuk juga masyarakat yang berekonomi kuat. ${ }^{8}$

Dalam rangka pembangunan di daerah, perlu terus dikembangkan dan ditingkatkan prakarsa dan partisipasi masyarakat termasuk di dalamnya lembaga swadaya masyarakat, serta peranan pemerintah daerah dalam pembangunan. Untuk itu ditingkatkan kemampuan pengelolaan pembangunan dari seluruh aparatur pemerintah di daerah sekaligus dalam rangka mewujudkan otonomi daerah yang lebih nyata dan bertanggung jawab. Pemerintah daerah yang dimaksud termasuk di dalamnya adalah Pemerintah Provinsi, Pemerintah Kabupaten/Kota. Sejalan dengan pemikiran ini, perlu terus dibangun dan ditingkatkan kemapuan daerah untuk membangun antara lain dengan menghimpun dana secara wajar dan tertib termasuk penggalian dana baru yang tidak bertentangan dengan kepentingan nasional.

Sebagian besar kantong-kantong kemiskinan berada di pedesaan. Oleh karena itu, usaha untuk mengentaskan kemiskinan seharusnya diupayakan dari pedesaan. Upaya tersebut antara lain ditempuh melalui pembentukan lembaga-lembaga swadaya masyarakat untuk menghimpun dana pembangunan daerah pedesaan khususnya. Pembangunan yang meliputi segala bidang kehidupan, tidak dapat dilakukan hanya oleh sebagian masyarakat, melainkan melibatkan partisipasi seluruh rakyat.

Pengesahan UU Cukai ini akan semakin memperkuat posisi cukai sebagai sumber pundi keuangan negara. Cukai menempati urutan ketiga sumber pendapatan negara. Dua besar masih didominasi hasil ekspor baik produk minyak dan gas (migas) maupun non migas serta berbagai jenis pajak. "Pada 2006, jumlah cukai mencapai Rp 38,5 triliun. Tahun ini meningkat Rp 3,5 triliun menjadi Rp 42 triliun. Ketentuan tentang bagi hasil tembakau dapat disimak pada Pasal 66 UU Cukai.

\footnotetext{
${ }^{8}$ Soemitro, Ronny H, Permasalahan Hukum di Dalam Masyarakat, (Bandunng : Alumni,1984), hlm. 73
} 


Pasal 66A
(1) Penerimaan negara dari cukai hasil tembakau yang dibuat di Indonesia dibagikan kepada
provinsi penghasil cukai hasil tembakau sebesar 2 persen yang digunakan untuk mendanai
peningkatan kualitas bahan baku, pembinaan industri, pembinaan lingkungan sosial, sosialisasi
ketentuan di bidang cukai, dan/atau pemberantasan barang kena cukai ilegal.
(4) Pembagian dana bagi hasil cukai hasil tembakau dilakukan dengan persetujuan Menteri,
dengan komposisi 30 persen untuk provinsi penghasil, 40 persen untuk kabupaten/kota daerah
penghasil, dan 30 persen untuk kabupaten/kota lainnya.
Pasal 66D
(1) Atas penyalahgunaan alokasi dana bagi hasil cukai hasil tembakau dapat diberikan sanksi
berupa penangguhan sampai dengan penghentian penyaluran dana bagi hasil cukai hasil tembakau
yang dibuat di Indonesia.
(2) Ketentuan lebih lanjut mengenai sanksi atas penyalahgunaan alokasi dana bagi hasil cukai
hasil tembakau diatur dengan peraturan menteri.

Ada satu poin baru yang cukup menarik, yakni dana bagi hasil untuk daerah penghasil tembakau. Ketentuan tersebut tertuang dalam Pasal 66A, 66B, 66C, dan 66D. Penerimaan negara dari cukai hasil tembakau akan dibagikan kepada provinsi penghasilnya sebesar 2 persen. Selanjutnya, realisasi dana segitu dibagikan kepada provinsi itu sendiri sebesar 30 persen, kota/kabupaten penghasil sebesar 40 persen $^{9}$, dan kota/kabupaten lainnya yang masih seprovinsi sebesar 30 persen. Caranya, lewat pemindahbukuan dari rekening kas umum negara ke rekening kas umum provinsi dan rekening kas umum kota/kabupaten. Tentu saja bagi-bagi hasil ini atas persetujuan Menteri Keuangan. Bagi hasil tersebut muncul dalam Dana Alokasi Umum (DAU) pada Anggaran Pendapatan dan Belanja Daerah (APBD). Setiap daerah juga harus siap. Ini berdampak peralihan belanja dari pusat ke daerah. Masalahnya, ada beberapa Kudusa. Misalnya persiapan pencairan APBD. Pemerintah juga perlu mempersiapkan instrumen aturan yang memperlancar belanja daerah.

\footnotetext{
${ }^{9}$ Daerah produsen cukai rokok yang meliputi 8 kabupaten yaitu Kabupaten Kudus, Kota Surabaya, Kota Kediri, Kota Malang, Kabupaten Malang, Kabupaten Kediri, dan Kabupaten Pasuruan.
} 
Berdasarkan Pasal 66A ayat (1), bagi hasil ini untuk bermacam tujuan yang sudah ditentukan, di antaranya untuk: mendanai peningkatan kualitas bahan baku, pembinaan industri, pembinaan lingkungan sosial, sosialisasi ketentuan di bidang cukai, serta pemberantasan Barang Kena Cukai (BKC) ilegal.

Situasi sulit akan dihadapi oleh pemerintah sebagai penyelenggara negara yang bertanggung jawab terhadap kesejahteraan rakyatnya. Di satu sisi, cukai rokok mempunyai posisi strategis untuk menyokong APBN (termasuk APBD), di sisi lain dampak akibat rokok perlu diKudusikan. Dewasa ini kampanye anti rokok serta adanya peraturan di tingkat daerah yang membatasi masyarakat untuk merokok jelas merupakan upaya untuk mengendalikan dampak rokok bagi kesehatan masyarakat. Kesadaran terhadap bahaya rokok terus ditingkatkan namun harapan perolehan "uang" dari sistem industri rokok tetap pula didambakan oleh jutaan penduduk, termasuk oleh Pemda (APBD) di daerah produsen rokok dan tembakau. Masyarakat kita belum sejahtera. Kelangkaan lapangan kerja di luar sistem produksi rokok memaksa penduduk (buruh, petani) sekaligus Pemda untuk melanggengkan industri rokok yang dipenuhi situasi dilematis ini. Rokok terbuat dari lintingan tembakau (Nicotania Tobacum). Sampai tahun 1920-an rokok dikenal luas sebagai penenang yang dapat membebaskan perokok dari kecemasan atau stress. Hal tersebut diperkuat oleh dukungan para dokter pada waktu itu. Baru setelah 70 tahun kemudian, pengaruh negatif rokok diketahui. Meskipun ditemui situasi yang dilematis, namun, upaya untuk keluar dari situasi dilematis ini tetap harus dilakukan baik oleh pemerintah maupun rakyat.

Setiap orang saya kira tahu betapa bahayanya rokok bagi kesehatan manusia. Bukan saja berbahaya bagi penghisapnya tetapi juga berbahaya bagi orang-rang yang berada di sekitarnya (perokok pasif). Memang belum ada studi atau penelitian yang menyajikan perbandingan antara biaya kesehatan yang dikeluarkan untuk membiayai penyakit akibat merokok dengan besarnya dana APBN maupun APBD yang diterima oleh Pemerintah. Imbangkah antara pendapatan dari rokok dengan bahaya akibat rokok bagi kesehatan manusia? Siapakah yang peduli dengan masalah ini? Mampukah cukai tembakau dapat secara signifikan menurunkan produksi dan konsumsi rokok? Apa akibatnya bila seluruh penduduk negeri ini tidak menghisap rokok? Bila produksi rokok berhenti, bagaimana nasib para pekerja di pabrik rokok? Bagaimana pula nasib petani tembakau? Bagaimana pula nasib APBN dan APBD? Vicious circle. Kita sulit untuk menentukan dari mana kita harus mengatasi masalah dilematis ini. 
Upaya sistematis dapat dilakukan oleh pemerintah dan masyarakat untuk mengatasi problematika di bidang industri rokok. Upaya-upaya tersebut antara lain:

1. Secara terencana pemerintah harus mulai mengarahkan alih tanaman bagi petani tembakau melalui program intensifikasi pertanian yang handal.

2. Negara (c.q. Pemerintah Pusat dan Daerah) secara terencana harus mengurangi ketergantungan APBN pada sumber cukai tembakau.

3. Petani harus mulai mengganti tanaman tembakau dengan tanaman lain sesuai dengan program intensifikasi pertanian pemerintah.

4. Penggunaan dana alokasi umum yang berasal dari DBH cukai tembakau harus tepat sasaran dan diarahkan pada rencana penurunan produksi rokok dengan mengalihkan pada produksi barang lainnya seperti kerajinan tangan, elektronik dll.

5. Pemerintah perlu merumuskan New Deal sebagai suatu program yang mereformasi sistem keuangan dan perbankan dan membuat banyak program untuk membantu para penganggur, melaksanakan jaminan sosial yang meliputi bantuan untuk para penganggur, jaminan untuk orang usia lanjut, orang cacat dan sebagainya. Di dalamnya termasuk program Agricultural Adjusment Administration Act (AAA) untuk memberikan subsidi kepada petani dan dapat memberikan Bantuan Langsung Tunai (BLT) kepada orang miskin.

6. Melakukan perbaikan nasib buruh dengan cara: (1) pemberian beasiswa bagi putraputri buruh, (2) memberikan tambahan penghasilan (tunjangan) bagi para pendidik yang mengelola lembaga pendidikan swasta yang kebanyakan berasal dari keluarga buruh, (3) membangun sarana dan prasarana pendidikan, (4) pemberian pelayanan hibah atau kredit lunak, (5) peningkatan jaminan kesehatan, (6) peningkatan sarana dan prasarana publik yang bermanfaat baik secara langsung atau tidak langsung terhadap produktivitas pabrik-pabrik penghasil cukai, serta (7) pemberian subsidi perumahan, dana rehab atau bedah rumah bagi para buruh yang tidak memiliki rumah atau memiliki rumah yang tidak layak huni.

Sebagaimana kita ketahui, pendapatan cukai tentu saja tidak lepas dari jerih payah para karyawan/buruh. Setiap hari sejak subuh para buruh/karyawan sudah berangkat kerja menuju brak-brak rokok untuk membuat lintingan batang per batang. Karena itu, pemerintah daerah perlu memperjuangkan konsep regulasi teknis untuk memikirkan nasib buruh/karyawan. Jika dilihat dari tingkat kesejahteraan, kehidupan 
para buruh tentu masih belum seluruhnya layak. Karena itu, pemerintah kabupaten perlu memprioritaskan nasib para buruh dalam regulasi di tingkat teknis dalam pengelolaan dana bagi hasil cukai tersebut.

Untuk mengakhiri perbincangan ini perlu saya sampaikan bahwa pada nilai keadilan sosial hendaknya menjadi visi utama dalam pengelolaan dana bagi hasil cukai tembakau. Kendati hukum memang seharusnya menjadi alat legitimasi kebijakan, tetapi pada suatu saat kita harus berani melakukan "rule breaking" sehingga kita menjadi lebih kreatif dalam penegakkan hukum agar tujuan sejati hukum untuk menciptakan kesejahteraan/kebahagiaan tercapai. Kita sadar betul bahwa pada waktu sakit, orang kadang terpaksa menelan pil pahit untuk menyembuhkan penyakitnya. Untuk tujuan ke depan demi kesejahteraan umat manusia secara bertahap masyakat Jawa Tengah harus melepaskan diri dari ketergantungannya terhadap industri rokok yang jelas berbahaya bagi kesehatan umat manusia.

\section{Konsep Hubungan Hukum dan Kemiskinan}

Dalam era industrialisasi sebagai ciri dunia ketiga, pada kenyatannya kemiskinan masih merupakan sosok yang nyata yang meliputi bagian besar penduduknya. Kemiskinan dapat terjadi disebabkan oleh karena lembaga-lembaga yang membentuk masyarakat yaitu pada tingkah laku yang berulang-ulang dari anggota masyarakatnya. Peraturan-peraturan hukum menetapkan norma-norma tingkah laku. Peraturan tersebut mengatur tentang segala sesuatu yang diperbolehkan dan sekaligus membatasi, di samping juga menentukan norma-norma yang tidak boleh dilakukan warga masyarakat yang dikenai sasaran peraturan tersebut.

Lebih lanjut Seidman berpendapat, bila para penguasa di dunia ketiga hendak merubah lembaga-lembaga masyarakat mereka harus menggunakan sistem hukum untuk menetapkan norma-norma tingkah laku baru dengan menghormati lembaga-lembaga yang dmaksud dan mengusahakan terbentuknya sarana-sarana untuk mendorong tingkah laku yang sesuai. Lembaga-lembaga sosial, politik dan ekonomi di dunia ketiga dapat menghasilkan kemiskinan untuk menggunakan sistem hukum guna mengubah lembaga-lembaga itu memerlukan sebuah modal yang menjelaskan bagaimana hukum memberikan pengaruh terhadap tingkah laku-tingkah 
laku dan kemudian menggunakan pengetahuan itu untuk mendorong terciptanaya tingkah laku baru ayng mengurangi kemiskinan. ${ }^{10}$

Sistem hukum dapat menimbulkan atau mempengaruhi tingkah laku warga masyarakat. Pernan ini hanya dapat dilakukan dengan persyaratan bahwa peraturan hukum ditetapkan berdasarkan kehendak sebagai variabel bebas (independent variabel). Sedangkan faktor-faktor yang mempengaruhi pemilihan dan pengidentifikasian sistem hukum dan sebagai variabel operasional atau penjelasan. Bekerjanya hukum dalam masyarakat melibatkan beberapa unsur atau aspek yang saling memiliki keterkaitan sebagai suatu sistem. Beberapa aspek tersebut yaitu: Lembaga Pembuat Hukum (Law Making Institutions), Lembaga Penerap Sanksi (Sanction Activity Institutions), Pemegang Peran (Role Occupant) serta Kekuatan Sosietal Personal (Societal Personal Force), Budaya Hukum (Legal Culture) ${ }^{11}$ serta unsur-unsur Umpan Balik (Feed Back) dari proses bekerjanya hukum yang sedang berjalan. Seidman juga menggambarkan model bekerjanya hukum dalam masyarakat untuk mengarahkan laku pemegang peran dengan diagram berikut :

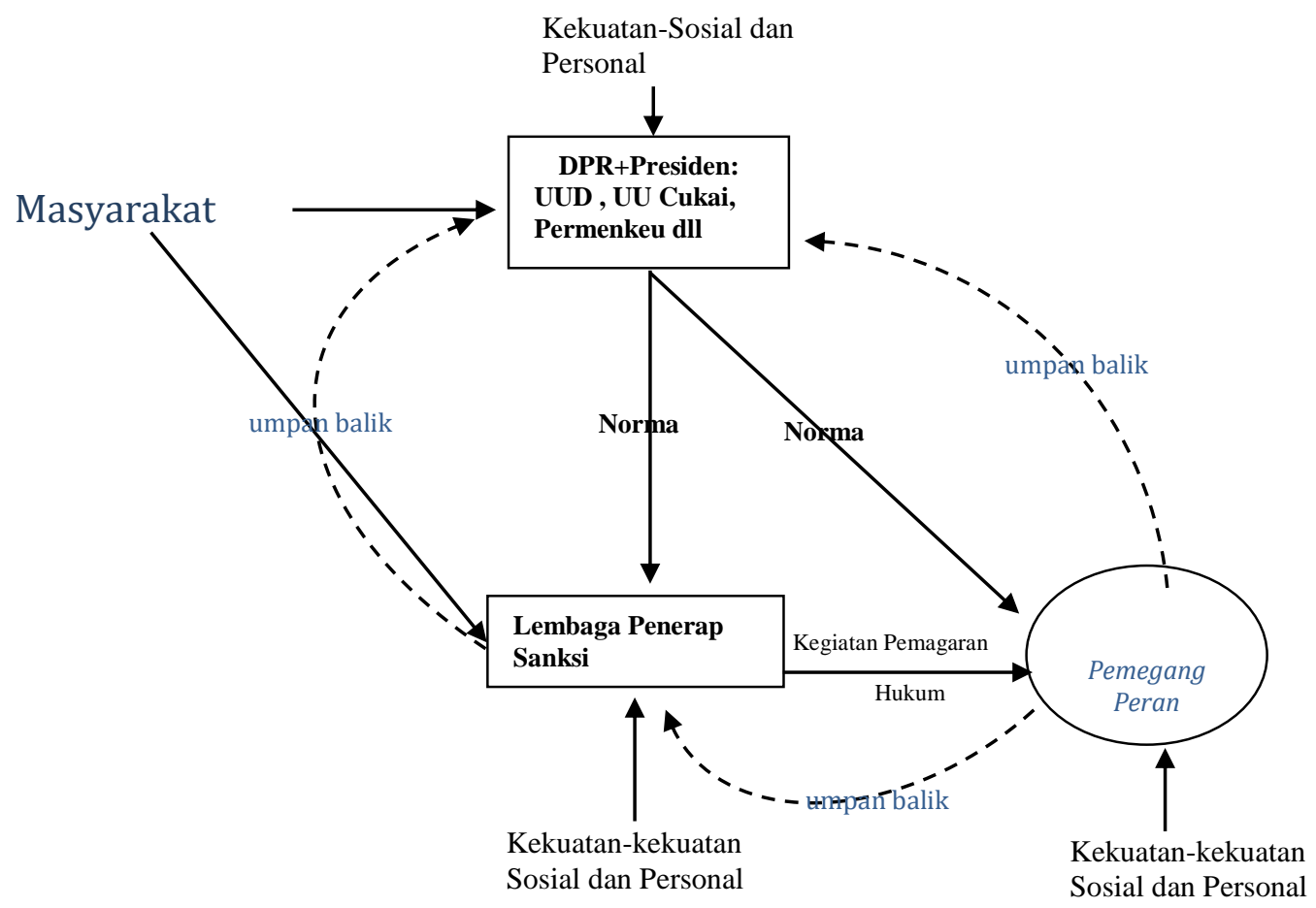

\footnotetext{
${ }^{10}$ Soemitro, Ronny H, Studi Hukum dan Kemiskinan, (Semarang : Tugu Muda, 1989), hlm. 9.

${ }^{11}$ Lihat, Lawrence M. Friedman, The Legal System, A Social Science Perspective, Russel Sage Foundation, New York, 1975, hlm. 14-15.
} 
Selanjutnya dikemukan alasan-alasan pemegang peran bertingkah laku seperti yang sesungguhnya mereka melakukan, berdasarkan norma tertentu yang oleh pembuat peraturan hukum ditunjukan pada mereka, yaitu :

1. Pemegang peran melakukan tingkah laku pilihan dari beberapa alternatif tingkah laku bila mereka memahami tingkah laku itu;

2. Tingkah laku antisipasi dari pihak lain merupakan bagian alternatif pilihan tiap pemegang peran dalam proses pembuatan hukum dan penegakannya;

3. Peranana pemegang peran ditentukan oleh norma-norma yang berlaku;

4. Sistem hukum terdiri dari norma-norma yang diundangkan oleh negara;

5. Setiap peraturan hukum yang ditujukan untuk merubah tingkah laku pemegang peran berarti merubah alternatif pilihan tingkah laku dengan merubah peraturan hukum itu sendiri dan dengan mengubah antispasi tingkah laku oleh pihak-pihak lain;

6. Dalam proses penyelenggaraan hukum, pemegang peran akan bertindak sesuai dengan peraturan hukum berdasar alasan-alasan yang disetujui oleh mereka dan tingkah laku yang ditujukan pada mereka dan karena kenyataan bahwa mereka menduduki peran dalam lembaga pengak hukum;

7. Dalam proses pembuatan hukum, pemegang peran akan bertindak sesuai dengan peraturan hukum berdasarkan alasan-alasan yang mereka setujui dan karena alasan tingkah laku yang ditujukan pada mereka dar peserta dalam proses penyelenggaraan peran dalam lembaga pembuat hukum; ${ }^{12}$

Dari uraian di atas kiranya dapat dipahami bahwa dalam menelaah hubungan hukum dan kemiskinan tidak dapat dilepaskan dari adanya konsep atau model bekerjanya hukum dalam masyarakat. Bertitik tolak dari batasan model yang tidak dikemukakan oleh Seidman, dapat diketahui dalam peranan hukum dalam mengubah dan mengarahkan perilaku atau pola-pola tingkah laku pemegang peran, dalam hal ini adalah warga masyarakat. Apabila perubahan perilaku ini dapat dilaksanakan maka hukum dalam bekerjanya dapat berfungsi sebagai sarana untuk merekayasa masyarakat (a tool of social Engineering). Dengan demikian pada tingkatan tertentu diharapkan hukum dapat menanggulangi bahkan menghapuskan kemiskinan.

${ }^{12}$ Soemitro, Ronny H, Perspektif Sosial Dlam Pemahaman Masalah-Masalah Hukum, (Semarang : Agung Press, 1989), hlm. 83-86. 
Sementara itu menurut Satjipto Rahardjo, dalam negara Indonesia yang berdasarkan hukum ini, cara-cara hukum memegang peranannya di bidang manajamen bidang-bidang kehidupan, seperti sosial dan ekonomi. Cara-cara tersebut pada akhirmnya akan mempertemukan usaha penggulangan kemiskinan dengan hukum. Lebih lanjut Satjipto Rahardjo menunjukan betapa komplek serta rumitnya interaksi masalah hukum dengan masalah sosial, dalam hal ini kemiskinan. Hukum yang diharapkan dapat untuk mencapai tujuan-tujuan yang diingunkan mungkin kurang berhasil untuk mengerjakannya. Bahkan secara sosiologis juga bis ditemukan keadaaa, bagaimana hukum justru merupakan hambatan dalam usaha menanggulangi kemiskinan. Bagi hukum sendiri, apabila segala sesuatunya telah dijalankan sesuai dengan prosedur hukum, maka masalahnya sudah diselesaikan dengan baik. ${ }^{13}$

Penyebaran hukum yang demikian luas ke dalam hampir setiap bidang kehidupan maka hukum itu bisa berfungsi sebagai penghambat dan Kudusa proses sosial, politik serta ekonomi yang berlangsung dalam masyarakat. Hal ini dapat dimengerti karena di negara yang berdasarkan hukum ini, setiap warga negara ingin meningkatkan kesejahteraan atau mencapai tingkat kehidupan yang lebih baik, harus berhadapan dengan hukum. Dengan demikian ia tidak dapat bertindak mengikuti proses alami, melainkan harus mengikuti jalur hukum. Pada keadaan tersebut hukum dapat menjadi Kudusa dan penghambat. ${ }^{14}$

Dengan memperhatikan kenyataan tersebut di muka, apa bila hukum diharapakan untuk bisa dipakai sebagai sarana penaggulangan masalah kemiskinan, maka usaha hendaknya dilakukkan dengan koordinasi, konsolodasi dan kerja sama yang lebih baik di bidang-bidang lain. Penangulangan masalah secara hukum saja tanpa bersama-sama denagn bidang lain niscaya akan mengurangi hasil yang dicapai, bahkan mungkin timbul akibat yang berlawanan. Pada akhirnya dikatakan bahwa penanganan masalah kemiskinan seyogyanya dilakukan secara holistik.

\footnotetext{
${ }^{13}$ Rahardjo, Satjipto, "Memikirkan Hubungan Hukum dan Kemiskinan”, Gema Keadilan, No.1 Tahun ke -15, 1991, hlm. 20.

${ }^{14} \mathrm{Ibid}$, hlm. 21.
}

Administrative Law \& Governance Journal. Volume 3 Issue 1, March 2020 


\section{B. Metode Penelitian}

Penelitian ini termasuk dalam tradisi penelitian kualitatif $^{15}$ dengan operasionalisasi penelitian yang berparadigma alamiah (naturalistic paradigm). ${ }^{16}$ Melalui penggunaan metode kualitatif diharapkan dapat ditemukan makna-makna yang tersembunyi di balik objek maupun subjek yang akan diteliti. Peneliti hendak mengkaji kelompok dan pengalaman-pengalaman yang sama sekali belum diketahui. ${ }^{17}$ Pada tradisi penelitian kualitatif tidak dikenal populasi karena sifat penelitiannya adalah studi kasus. Objek yang diteliti berupa domain-domain atau situasi sosial tertentu yang meliputi tempat, pelaku dan kegiatan. Domain tersebut terdiri dari: (1) Lembaga Pembuat Hukum (Law Making Institution), di dalamnya termasuk DPRD-Pemerintah Provinsi/Kabupaten, (2) Pemegang Peran (Role Occupant), yang di dalamnya termasuk LSM, masyarakat penerima DBHCHT dan (3) Lembaga Penerap Sanksi (Sanction Activity Institutions) atau Lembaga Penegak Hukum, yang termasuk di dalamnya adalah Pemerintah Daerah (4) Domain Kepakaran, yang terdiri dari informan pakar dari beberapa ilmu yaitu Politik Hukum. Responden yang disebut sebagai informan ditentukan secara purposive. ${ }^{18}$ Yang dikenal adalah key-informan, informan yang jumlahnya tidak ditentukan secara limitatif melainkan mengikuti prinsip snowball. Instrumen penelitian adalah peneliti sendiri. Pada penelitian kualitatif interpretif atau konstruktivis maka motif penelitian adalah untuk (1) to explore (2) to critizise (3) to understand sebagaimana telah disinggung sebelumnya.

\footnotetext{
15 Penelitian kualitatif mempunyai iterasi empat unsur, yaitu: (1) Pengambilan/penentuan sampel secara purposive; (2) Analisis induktif; (3) Grounded Theory; (4) Desain sementara akan berubah sesuai dengan konteksnya. Lihat, Noeng Muhadjir, Metodologi Penelitian Kualitatif, Penerbit Rake Sarasin, Yogyakarta, 2002, hlm. 165-168.

${ }^{16}$ Paradigma ini berangkat dari pandangan Max Weber yang kemudian dikembangkan lebih lanjut oleh Irwin Deutcher yang lebih populer dengan sebutan "phenomenologis". Paradigma ini mendasari aksiomanya pada "the naturalistic ecological theory" dan "the qualitative phenomenological theory", yang kalau diringkas, meurut Guba dan Lincoln, bertumpu pada 5 aksioma. Lihat, Lexy J. Moleong, Metodologi Penelitian Qualitatif, PT Remaja Rosdakarya, Bandung, hlm. 31-32. Bandingkan dengan Zamroni, Pengantar Pengembangan Teori Sosial, PT Tiara Wacana Yogya, Yogyakarta, 1992, hlm. 80-81. Bandingkan dengan pusat perhatian penelitian kualitatif dan sifat penelitian kualitatif yang holistik dalam Burhan Ashshofa, Metode Penelitian Hukum, Rineka Karya, Jakarta, 1998, hlm. 20-21 dan Hadari Nawaai dan Mimi Martini, Penelitian Terapan, Gadjah Mada University Press, Yogyakarta, 1996, hlm. 175.

${ }^{17}$ Robert Bogdan \& Steven J Taylor, Dasar-Dasar Penelitian Kualitatif (Penerjemah: A. Khozin Afandi), Usaha nasional, Surabaya, 1993, hlm. 30-31.

${ }^{18}$ Sampel yang purposive adalah sampel yang dipilih dengan cermat sehingga relevan dengan tujuan penelitian, yang memiliki ciri-ciri khusus dan esensial. Semua ini tergantung pada pertimbangan atau penilaian (judgment) dari peneliti. Oleh karena itu, purposive sampling juga disebut dengan Judgmental Sampling. Lihat, Soeratno dan Lincoln Arsyad, Metodologi Penelitian Untuk Ekonomi dan Bisnis, Unit Penerbitan dan Percetakan APMP YKPN, Yogyakarta, 1993, hlm. 119-120.
} 
Administrative Law \& Governance Journal. Volume 3 Issue 1, March 2020 ISSN. 2621-2781 Online

\section{Pembahasan}

\section{Deskripsi Kondisi Sosial Ekonomi Kabupaten Kudus Terkait dengan Penerimaan DBHCHT}

Kemiskinan merupakan permasalahan secara global, terlebih pada negaranegara berkembang seperti Indonesia ini, pada tahun 2013 lalu, studi yang dilakukan oleh gallup $^{19}$ melakukan penelitian di 131 negara yang ditelitinya, sebanyak satu dari lima orang hidup di bawah tekanan parah kemiskinan dengan pendapatan US\$1,25 atau Rp 15.250 per hari . Dalam kondisi tersebut, Bank Dunia mendeklarasikan tujuan barunya untuk menekan tingkat kemiskinan di bawah $3 \%$ pada $2030^{20}$.

Penanggulangan Kemiskinan adalah kebijakan dan program pemerintah dan pemerintah daerah yang dilakukan secara sistematis, terencana, dan bersinergi dengan dunia usaha dan masyarakat untuk mengurangi jumlah penduduk miskin dalam rangka meningkatkan derajat kesejahteraan rakyat. Berdasarkan Peraturan Presiden Republik Indonesia Nomor 15 Tahun 2010 Tentang Percepatan Penanggulangan Kemiskinan, dalam upaya menanggulangi kemiskinan pemerintah melaukan beberapa strategi penanggulangan kemiskinan berupa: a. Rencana Pembangunan Jangka Panjang, b. Rencana Pembangunan Jangka Panjang Daerah. Terdapat beberapa upaya penanggulangan kemiskinan dengan adanya strategi percepatan penanggulangan kemiskinan dengan : Mengurangi beban pengeluaran masyarakat miskin; Meningkatkan kemampuan dan pendapatan masyarakat miskin; Mengembangkan dan menjamin keberlanjutan Usaha Mikro dan Kecil; Mensinergikan kebijakan dan program penanggulangan kemiskinan.

Rencana aksi penanggulangan kemiskinan di Kabupaten Kudus dirumuskan secara konkret dalam wujud kebijakan dan strategi penanggulangan kemiskinan yang terintegrasi dalam sistem perencanaan pembangunan Kabupaten Kudus, mulai dari RPJPD Tahun 2005 - 2025, RPJMD Tahun 2010 - 2015, Rencana Kerja Pemerintah Daerah (RKPD), Rencana Aksi Daerah (RAD) Millenium Development Goals), serta Strategi Penanggulangan Kemiskinan Daerah (SPKD).

\footnotetext{
${ }^{19}$ www.gallup.com, Gallup delivers forward-thinking research, analytics, and advice to help leaders solve their most pressing problems. Combining more than 75 years of experience with its global reach, Gallup knows more about the attitudes and behaviors of the world's constituents, employees, and customers than any other organization.

${ }^{20} \mathrm{http}$ ://bisnis.liputan6.com/read/784268/sepertiga-orang-dunia-hidup-menderita-di-bawah-garis-kemiskinan.
}

Administrative Law \& Governance Journal. Volume 3 Issue 1, March 2020 
Tingkat kemiskinan di Kabupaten Kudus, Jawa Tengah, pada 2016 mengalami penurunan menjadi 7,65\% dibandingkan dengan tingkat kemiskinan pada 2015 yang mencapai 7,73\% dari seluruh warga kabupaten kretek itu. Bahkan, Kabupaten Kudus menempati urutan ketiga tingkat Jateng untuk persentase penduduk miskin terendah sebesar 7,65\% di tahun 2016. ${ }^{21}$ Ida Sodriarini yang mewakili Kepala BPS Kudus Sapto Harjuli Wahyu lalu memaparkan urutan pertama terendah untuk angka kemiskinan di Jateng dipegang Kota Semarang dengan 4,85\%, diikuti Kota Salatiga dengan persentase penduduk miskinnya 5,24\%. Jika dilihat di kabupaten-kabupaten tetangga, maka Kabupaten Kudus memiliki persentase penduduk miskin paling kecil. Di urutan berikutnya adalah Kabupaten Jepara dengan persentase 8,35\% dan Kabupaten Pati sebesar 11,65\%. Adapun jumlah penduduk di Kabupaten Kudus pada tahun 2015 sebanyak 831.300 jiwa, sedangkan tahun 2016 naik menjadi 841.500 jiwa.

Jumlah penduduk sejak tahun 2012 hingga 2016 mengalami tren kenaikan, karena tahun 2012 tercatat hanya 800.400 jiwa, kemudian naik menjadi 810.890 jiwa pada tahun 2013 dan naik lagi menjadi 821.110 jiwa pada tahun 2014. Untuk menentukan penduduk miskin, katanya, bisa dilihat dari garis kemiskinan dengan standar survei pengeluaran makanan dan non makanan. Pada tahun 2015, katanya, ukuran standar kemiskinan ditetapkan sebesar Rp328.404/orang/bulan, sedangkan tahun 2016 naik menjadi Rp 356.951/orang/bulan. Masyarakat yang masuk kategori miskin, katanya, dihitung dari tingkat konsumsinya di bawah 2.100 kilokalori per kapita. Tahun ini, kami juga kembali menggelar survei sosial ekonomi untuk mengetahui jumlah kemiskinan di Kabupaten Kudus

Selain Percepatan Penanggulangan Kemiskinan untuk menanggulangi tingkat kemiskinan yang berada di Kabupaten Kudus, Pemerintah Kabupaten Kudus melakukan program-program antara lain. Pertama, Bantuan Sosial terpadu berbasis keluarga, berupa program Jaminan Kesehatan Masyarakat (Jamkesmas) sekarang berubah menjadi Badan Penyelenggara Jaminan Sosial (BPJS), dan Beras untuk Keluarga Miskin (Raskin), serta Program Keluarga Harapan (PKH). Kedua, Penanggulangan Kemiskinan berbasis pemberdayaan masyarakat seperti program Nasional Pemberdayaan Masyarakat (PNPM) dan Bantuan Siswa Miskin. Ketiga, Perluasan Kesempatan kerja, pemberdayaan tenaga kerja, dan perlindungan sosial, serta penanggulangan kemiskinan berbasis pemberdayaan

\footnotetext{
${ }^{21}$ Pernyataan Kasi Statistik Sosial Ida Sofriarini di Kudus, Senin (28/8/2017) kepada Wartawan SAPA Indonesia.
} 


\section{Administrative Law \& Governance Journal. Volume 3 Issue 1, March 2020 ISSN. 2621-2781 Online}

usaha ekonomi dan mikro seperti : pemberian Kredit Usaha Rakyat (KUR) dan Kredit Usaha Bersama (KUBE).

Realisasi Pendapatan Asli Daerah (PAD) Kabupaten Kudus, Jawa Tengah, hingga semester pertama tahun 2017 mencapai Rp137,62 miliar atau 39,41 persen dari target selama setahun sebesar Rp 349,19 miliar. Penerimaan asli daerah yang direncanakan sebesar Rp 349,19 miliar itu, berasal dari empat jenis penerimaan. Hal tersebut dinyatakan oleh Kepala Badan Pengelolaan Pendapatan, Keuangan dan Aset Daerah Kabupaten Kudus Eko Djumartono di Kudus, September 2018. Keempat jenis penerimaan tersebut, di antaranya dari pajak daerah, retribusi daerah, hasil pengelolaan kekayaan daerah yang dipisahkan, serta lain-lain PAD yang sah.

Data terakhir kependudukan tahun 2015 menyebutkan jika jumlah penduduk di Kabupaten Kudus sebanyak 831.303 jiwa dengan luas wilayah sebesar 425,16 kilometer persegi, menjadikan tingkat kepadatan penduduk di Kabupaten Kudus sebesar 1.955 jiwa per kilometer persegi. Untuk mengetahui jumlah penduduk Kudus saat ini, isknews.com mengunjungi Badan Pusat Satatistik Kabupaten Kudus. Di sana data kependudukan dihimpun dalam buku Kabupaten Kudus dalam Angka 2017, berikut beberapa ulasan terkait data kependudukan yang tertuang dalam buku tersebut.

Berdasarkan data sensus yang direkam Badan Pusat Statistik Kabupaten Kudus pada tahun 2016 menyebutkan, bahwa jumlah penduduk Kabupaten Kudus pada tahun 2016 sebesar 841.499 jiwa. Dilihat dari banyaknya penduduk berdasarkan jenis kelamin diketahui 414.315 jiwa laki-laki (49,24 persen) dan 427.184 jiwa perempuan (50,76 persen). Data menunjukkan, jumlah penduduk perempuan lebih banyak, dibandingkan jumlah penduduk laki-laki. Bila dilakukan berbandingan rasio jumlah penduduk laki-laki dan perempuan didapatkan hasil 96,99, yang menunjukkan bahwa setiap 100 penduduk perempuan terdapat 97 penduduk laki-laki. Hal senada terjadi di setiap kecamatan di Kabupaten Kudus yang memiliki rasio jenis kelamin berkisar antara 94,24 hingga 98,30.

Jika dilihat berdasarkan penyebaran penduduk di Kabupaten Kudus, daerah dengan jumlah penduduk tertinggi ada di Kecamatan Jati, yakni sebanyak 108.103 jiwa. Disusul Kecamatan Jekulo sebanyak 107. 336 jiwa dan Kecamatan Dawe sebanyak 107.00 jiwa. Sedangkan untuk daerah dengan jumlah penduduk terkecil ada di Kecamatan Bae yakni sebanyak 72.627 jiwa. Meskipun demikian, luas wilayah Kecamatan Bae yang cukup kecil yakni sebesar 23,32 kilometer persegi menjadikan 
Administrative Law \& Governance Journal. Volume 3 Issue 1, March 2020 ISSN. 2621-2781 Online

wilayah ini termasuk kedalam daerah dengan tingkat kepadatan penduduk yang cukup tinggi.

Beranjak ke tingkat kepadatan penduduk di Kabupaten Kudus, masih didominasi oleh daerah di pusat Kota, seperti Kecamatan Kudus. Dengan luas wilayah terkecil yaitu sebesar 10,47 kilometer persegi dengan jumlah penduduk mencapai 98.363 jiwa, menjadikan Kecamatan Kudus sebagai daerah dengan tingkat kepadatan penduduk tertinggi di Kabupaten Kudus, yakni sebesar 9.392 jiwa per kilometer persegi

\section{Kebijakan Pengaturan (formulasi) Penggunaan Alokasi Dana Bagi Hasil Cukai Hasil Tembakau (DBHCHT) Terkait Dengan Program Pembinaan Lingkungan Sosial}

Sebagaimana diatur oleh Undang-Undang 25 tahun 2004 tentang Perencanan Pembangunan Nasional dan Peraturan Pemerintah Nomor 8 tahun 2008 tentang Tahapan, Tatacara Penyusunan, Pengendalian dan Evaluasi Pelaksanaan Rencana Pembangunan Daerah, Pejabat pada Pemerintah Daerah berkedudukan sebagai unsur pelaksana dari kebijakan yang ditetapkan Kepala Daerah (eksekutif) dan Dewan Perwakilan Rakyat Daerah (legislatif) baik kebijakan jangka panjang untuk masa waktu 20 tahun (RPJPD), Menengah untuk masa waktu 5 tahun (RPJMD) dan Pendek untuk masa tahunan (RKPD) Dengan kedudukan sebagai pelaksana tersebut maka baik tidaknya program yang dibuat dari aspek teknis ditentukan oleh kualitas birokrat itu sendiri, akan tetapi dari aspek kebijakan ditentukan oleh Kepala Daerah dan DPRD.

Berdasarkan fakta tersebut dalam tataran kebijakan penuntasan kemiskinan ini, maka Pemerintah Daerah baik eksekutif, legislatif dan birokrat menindaklanjuti dengan langkah kongkrit melalui komitmen, kebijakan-program-kegiatan yang terstruktur, dukungan sumber daya-dana dan politik serta kejujuran-keihlasan untuk memerangi kemiskinan didaerah. Langkah-langkah kongkrit tersebut misalnya dengan menumbuhkan kejujuran dan profesionalisme birokrat, menyempurnakan dan memantapkan manajemen pengelolaan di daerah; memantapkan dan mengembangkan program pro-orang miskin oleh pemerintah daerah dan memantapkan komitmen politik terhadap program penuntasan kemiskinan di daerah. Keempat langkah 
Administrative Law \& Governance Journal. Volume 3 Issue 1, March 2020 ISSN. 2621-2781 Online

ini haruslah dijalankan oleh Pemerintah Daerah untuk mendapatkan dukungan riil pembiayaan dari Pemerintah Pusat melalui berbagai Kementerian Negara yang terkait serta untuk mendapatkan dukungan dari berbagai elemen baik swasta dan masyarakat.

Dari aspek dukungan sumber daya dana, pemerintah daerah dapat menggunakan DBHCHT untuk mendukung langkah-langkah strategis dalam pengentasan kemiskinan. Kebijakan alokasi DBHCHT pun masih menjadi masalah terutama tentang alokasi dana dan penyerapannya yang tidak maaksimal. Di samping itu, masalah penyusunan berbagai kebijakan program kemiskinan selama ini masih ditemukan kesalahan dalam pendekatan (paradigma) baik didalam perumusan kebijakan, strategi, program dan kegiatan yang masih berpijak pada blueprint approach sebagaimana lazim diterapkan pada bidang-bidang tehnik, sedangkan kemiskinan adalah masalah sosial-ekonomi. Langkah berikutnya adalah pentingnya mengubah pola sikap pejabat melihat para pihak yang terlibat dalam pengentasan kemiskinan. Seringkali si-miskin hanya dianggap sebagai objek belaka. Pola pikir ini dapat diubah kearah proses pemberdayaan terhadap kaum miskin yang tidak hanya sebagai objek tetapi juga si-miskin dijadikan sebagai subjek.

Rencana Kerja Pemerintah Daerah (RKPD) Kabupaten Kudus Tahun 2017 merupakan pelaksanaan tahun ke-4 RPJMD Kabupaten Kudus Tahun 2013-2018. Penyusunan RKPD Tahun 2017 berpedoman pada Undang-Undang Nomor 25 Tahun 2004 tentang Sistem Perencanaan Pembangunan Nasional, Undang-undang Nomor 23 tahun 2014 tentang Pemerintahan Daerah sebagaimana telah diubah beberapa kali terakhir dengan Undang-Undang Nomor 9 Tahun 2015 tentang Perubahan Kedua Atas Undang-undang Nomor 23 tahun 2014 tentang Pemerintahan Daerah, Peraturan Pemerintah Nomor 8 Tahun 2008 tentang Tahapan, Tata Cara Penyusunan, Pengendalian dan Evaluasi Pelaksanaan Rencana Pembangunan Daerah, dan Peraturan Menteri Dalam Negeri Nomor 54 tahun 2010 tentang Pelaksanaan Peraturan Pemerintah Nomor 8 Tahun 2008. Penyusunan RKPD Kabupaten Kudus mengacu pada RPJPD Kabupaten Kudus Tahun 2005-2025, RPJMD Kabupaten Kudus Tahun 2013-2018, Rencana Kerja Pemerintah (RKP) Tahun 2016, dan RKPD Provinsi Jawa Tengah Tahun 2016. Sebagaimana tercantum dalam RPJMD, citacita pembangunan Kabupaten Kudus yang ingin dicapai dalam kurun waktu tahun 20132018 yaitu “Terwujudnya Kudus Yang Semakin Sejahtera”. Pembangunan pada tahun 2016 
RPJMD diarahkan untuk melanjutkan tahapan pembangunan tahun sebelumnya yang belum selesai. Tema pembangunan Kabupaten Kudus tahun 2017 yaitu : "Peningkatan kualitas pelayanan dasar dan publik serta perekonomian daerah dengan didukung infrastruktur yang memadai." Arah kebijakan pembangunan difokuskan untuk pengembangan fasilitasi permodalan UMKM dan perluasan pemasaran produk UMKM, peningkatan mutu pendidikan, perluasan pelayanan kesehatan, peningkatan kompetensi tenaga kerja, pengembangan infrastruktur dan sarpras penunjang, penguatan birokrasi pemerintahan dan peningkatan pelayanan publik serta pelestarian budaya daerah. Di samping itu dalam peningkatan infrastruktur diupayakan pendekatan kewilayahan dengan prioritas tahun 2016 di Kecamatan Kaliwungu, Kecamatan Mejobo dan Kecamatan Bae. Fokus pembangunan diarahkan untuk percepatan pencapaian target dan prioritas sasaran pembangunan pada 4 (empat) pilar pembangunan, meliputi : (1) pemberdayaan Usaha Mikro, Kecil dan Menengah (UMKM) bagi peningkatan kesejahteraan masyarakat; (2) mewujudkan wajib belajar 12 (dua belas) tahun yang terjangkau dan berkualitas; (3) tersedianya fasilitas dan pelayanan kesehatan yang murah dan terjangkau; dan (4) perlindungan usaha dan kesempatan kerja secara luas dan menyeluruh. Selain itu pembangunan juga difokuskan pada peningkatan kualitas SDM yang religius dan berbudaya serta memiliki kompetensi dan daya saing global.

Dengan diundangkannya Peraturan Menteri Keuangan Nomor 222/PMK.07/2017 tentang Penggunaan, Pemantauan, dan Evaluasi Dana Bagi Hasil Cukai Hasil Tembakau, maka Peraturan Bupati Kudus Nomor 14 Tahun 2016 tentang Pedoman Pengelolaan Dana Bagi Hasil Cukai Hasil Tembakau di Kabupaten Kudus sudah tidak sesuai lagi, sehingga perlu diganti. Kebijakan pengaturan penggunaan DBHCHT di Kabupaten Kudus dapat dilihat mulai diberlakukannya Undang-Undang No 39 Tahun 2007 sebagai Revisi UU 11/1995 tentang Cukai hingga PERATURAN BUPATI KUDUS NOMOR 7 TAHUN 2018 TENTANG PEDOMAN PENGELOLAAN DANA BAGI HASIL CUKAI HASIL TEMBAKAU DI KABUPATEN KUDUSPERATURAN BUPATI KUDUS NOMOR 7 TAHUN 2018 TENTANG PEDOMAN PENGELOLAAN DANA BAGI HASIL CUKAI HASIL TEMBAKAU DI KABUPATEN KUDUS.

Pada Pasal 2 disebutkan bahwa: (1) Pengelolaan DBHCHT dilaksanakan dengan berpedoman pada peraturan perundang-undangan yang berlaku, sesuai prioritas dan karakteristik daerah. (2) Pengelolaan DBHCHT di Kabupaten Kudus dilaksanakan oleh Perangkat Daerah terkait sesuai kebutuhan dibawah koordinasi Asisten Ekonomi, 
Administrative Law \& Governance Journal. Volume 3 Issue 1, March 2020 ISSN. 2621-2781 Online

Pembangunan, dan Kesejahteraan Rakyat. (3) Asisten Ekonomi, Pembangunan, dan Kesejahteraan Rakyat dalam melaksanakan koordinasi sebagaimana dimaksud pada ayat (2) dibantu oleh Kepala Bagian Perekonomian selaku Sekretariat. (4) Pedoman Pengelolaan DBHCHT sebagaimana dimaksud pada ayat (1) sebagaimana tercantum dalam Lampiran Peraturan Bupati ini.

Keputusan Bupati Nomor 7 TAHUN 2018 tentang penetapan alokasi dana bagi hasil cukai hasil tembakau di kabupaten Kudus tahun 2018. Beberapa kebijakan peraturan terkait dapat disebutkan sebagai berikut:

1. Peningkatan Kualitas Bahan Baku

2. Pembinaan Industri

3. Pembinaan Lingkungan Sosial

4. Sosialisasi Ketentuan di bidang Cukai

5. Pemberantasan Barang Kena Cukai Ilegal

Oleh karena itu penggunaan alokasi DBHCHT Kabupaten Kudus juga mendukung pencapaian tujuan pengenaan cukai hasil tembakau $(\mathrm{CHT})$ yaitu:

1. Pengendalian Konsumsi

2. Pengawasan Peredaran

3. Mitigasi Dampak Negatif

4. Optimalisasi Penerimaan Negara

Dalam pengelolaan alokasi dana bagi hasil cukai tembakau DBHCHT di Kabupaten Kudus untuk tahun anggaran tahun 2016, 2017, dan 2018 tampak sekali adanya alokasi anggaran pada bebarapa SKPD yang digunakan untuk program penguatan perekonomian dalam rangka pengentasan kemiskinan. Daftar alokasi anggaran tersebut dapat dilihat dalam lampiran laporan penelitian ini.

\section{Tabel 1}

Daftar pengelola alokasi dana bagi hasil cukai hasil tembakau (DBHCHT) kabupaten Kudus tahun anggaran 2018

\begin{tabular}{|l|l|l|c|}
\hline No & SKPD & KEGIATAN & $\begin{array}{l}\text { APBD } \\
\text { PERUBAHAN }\end{array}$ \\
\hline 1 & 2 & 4 & 6 \\
\hline 1 & RSU & $\begin{array}{l}\text { Peningkatan derajat kesehatan masyarakat dengan } \\
\text { menyediakan fasilitas perawatan kesehatan bagi } \\
\text { penderita akibat dampak asap rokok }\end{array}$ & 21.799 .990 .000 \\
\hline
\end{tabular}

Administrative Law \& Governance Journal. Volume 3 Issue 1, March 2020 
Administrative Law \& Governance Journal. Volume 3 Issue 1, March 2020 ISSN. 2621-2781 Online

\begin{tabular}{|c|c|c|c|}
\hline & & Pengadaan alat-alat kesehatan rumah sakit & 5.000 .000 .000 \\
\hline 2 & DinsosKB & $\begin{array}{l}\text { Penguatan ekonomi masyarakat di lingkungan IHT } \\
\text { dalam rangka pengentasan kemiskinan, } \\
\text { mengurangi pengangguran, dan mendorong } \\
\text { pertumbuhan ekonomi daerah melalui } \\
\text { pengembangan usaha bagi perempuan }\end{array}$ & 2.000 .000 .000 \\
\hline \multirow[t]{12}{*}{3} & NekerPerinkop & $\begin{array}{l}\text { Penguatan ekonomi masyarakat di lingkungan IHT } \\
\text { dalam rangka pengentasan kemiskinan, } \\
\text { mengurangi pengangguran, dan mendorong } \\
\text { pertumbuhan ekonomi daerah melalui } \\
\text { pengembangan industri berbasis teknologi }\end{array}$ & 529.325 .000 \\
\hline & & $\begin{array}{l}\text { Pembinaan kemampuan dan ketrampilan kerja } \\
\text { masyarakat dilingkungan IHT }\end{array}$ & 8.912 .000 .000 \\
\hline & & $\begin{array}{l}\text { Penguatan sarana dan prasarana kelembagaan } \\
\text { pelatihan bagi tenaga kerja industri hasil tembakau } \\
\text { melalui Pengadaan Peralatan Ketrampilan }\end{array}$ & 250.000 .000 \\
\hline & & $\begin{array}{l}\text { Penguatan sarana dan prasaranan Kelembagaan } \\
\text { Pelatihan bagi Tenaga Kerja Industri Hasil } \\
\text { Tembakau melalui Pemeliharaan Sarpras BLK }\end{array}$ & 243.000 .000 \\
\hline & & $\begin{array}{l}\text { Penguatan Sarana dan Prasarana Kelembagaan } \\
\text { Pelatihan bagi Tenaga kerja IHT Melalui } \\
\text { Rehabilitasi Sedang/Berat Sarpras BLK }\end{array}$ & 4.475 .000 .000 \\
\hline & & $\begin{array}{l}\text { Penyebarluasan Informasi Bursa Tenaga } \\
\text { Kerja(DBHCHT) }\end{array}$ & 390.000 .000 \\
\hline & & $\begin{array}{l}\text { Pengembangan Kelembagaan Produktivitas dan } \\
\text { Pelatihan Kewirausahaan (DBHCHT) }\end{array}$ & 300.000 .000 \\
\hline & & $\begin{array}{l}\text { Peningkatan Produktivitas Sektor Formal dan } \\
\text { Informal (DBHCHT) }\end{array}$ & 200.000 .000 \\
\hline & & $\begin{array}{l}\text { Pembinaan kemampuan ketrampilan kerja } \\
\text { masyarakat di lingkungan IHT ( DBHCHT ) }\end{array}$ & 425.000 .000 \\
\hline & & $\begin{array}{l}\text { Penguatan ekonomi masyarakat di lingkungan IHT } \\
\text { dalam rangka pengentasan } \\
\text { kemiskinan,mengurangi pengangguran, dan } \\
\text { mendorong pertumbuhan ekonomi daerah melalui } \\
\text { pengembangan usaha mikro kecil dan menengah }\end{array}$ & 743.860 .000 \\
\hline & & $\begin{array}{l}\text { Pengembangan sarana laboratorium uji dan } \\
\text { pengembangan metode pengujian }\end{array}$ & 675.675 .000 \\
\hline & & $\begin{array}{l}\text { Penguatan ekonomi masyarakat dilingkungan } \\
\text { industri hasil tembakau dalam rangka pengentasan } \\
\text { kemiskinan mengurangi pengangguran dan } \\
\text { mendorong pertumbuhan ekonomi daerah melalui } \\
\text { pembinaan ketrampilan industri hulu hilir }\end{array}$ & 2.200 .000 .000 \\
\hline 4 & Satpol PP & Pemberantasan barang kena cukai ilegal & 200.000 .000 \\
\hline \multirow[t]{2}{*}{5} & Dis Dag sar & $\begin{array}{l}\text { Pembangunan Promosi Perdagangan Internasional } \\
\text { (DBHCHT) }\end{array}$ & - \\
\hline & & Promosi Perdagangan Regional (DBHCHT) & - \\
\hline 6 & Dinas PKPLH & $\begin{array}{l}\text { Penerapan menajemen limbah industri hasil } \\
\text { tembakau yang mengacu kepada analisis dampak } \\
\text { lingkungan }\end{array}$ & 200.000 .000 \\
\hline
\end{tabular}

Administrative Law \& Governance Journal. Volume 3 Issue 1, March 2020 
Administrative Law \& Governance Journal. Volume 3 Issue 1, March 2020 ISSN. 2621-2781 Online

\begin{tabular}{|c|c|c|c|}
\hline & & $\begin{array}{l}\text { Rehab/Pemeliharaan Lampu Penerangan } \\
\text { Jalan/KWh Meter }\end{array}$ & - \\
\hline & & Penataan RTH & - \\
\hline & & Pemeliharaan RTH & - \\
\hline 7 & Pariwisata & $\begin{array}{l}\text { Pembinaan Kemampuan dan Ketrampilan kerja } \\
\text { masyarakat di Desa Wisata di lingkungan IHT } \\
(\mathrm{DBHCHT})\end{array}$ & 100.000 .000 \\
\hline \multirow[t]{5}{*}{8} & Dinas PUPR & Pembangunan Jalan & 22.150 .000 .000 \\
\hline & & Rehabilitasi/pemeliharaaan Jalan & 11.800 .000 .000 \\
\hline & & Pembangunan Saluran Drainase/Gorong-Gorong & 4.675 .000 .000 \\
\hline & & $\begin{array}{l}\text { Rehabilitasi/Pemeliharaan Saluran } \\
\text { Drainase/Gorong-Gorong }\end{array}$ & 3.481 .934 .000 \\
\hline & & Pembangunan/Peningkatan Infrastruktur & - \\
\hline 9 & $\begin{array}{l}\text { Dinas } \\
\text { Kominfo }\end{array}$ & Penyebarluasan Informasi Pembangunan Daerah & - \\
\hline \multirow[t]{9}{*}{10} & Dinas PUPR & Pembangunan Jembatan & 6.500 .000 .000 \\
\hline & & Pembangunan Turap/Talud/Bronjong & 2.835 .000 .000 \\
\hline & & Pembangunan/Peningkatan Infrastruktur & - \\
\hline & & Pemeliharaan dan Rehabilitasi Embung & - \\
\hline & & Pembangunan Resevoir Pengendali Banjir & - \\
\hline & & Rehabilitasi/pemeliharaaan Jembatan & 3.150 .000 .000 \\
\hline & & Rehabilitasi/pemeliharaaan Talud/Bronjong & - \\
\hline & & Rehabilitasi/pemeliharaaan Jaringan Irigasi & - \\
\hline & & $\begin{array}{l}\text { Rehabilitasi/pemeliharaaan Normalisasi Saluran } \\
\text { sungai }\end{array}$ & - \\
\hline 11 & Dishub & Pembangunan Terminal Wisata & - \\
\hline \multirow[t]{6}{*}{12} & DKK & $\begin{array}{l}\text { Pengadaan, Peningkatan, dan Perbaikan Sarana } \\
\text { dan Prasarana Puskesmas dan Jaringannya }\end{array}$ & 6.890 .473 .000 \\
\hline & & $\begin{array}{l}\text { Pelayanan Kesehatan Gratis Puskesmas dan } \\
\text { Jaringannnya }\end{array}$ & - \\
\hline & & Pemeliharaan Rutin/Berkala Gedung Kantor & 200.640 .000 \\
\hline & & Pemeliharaan Sedang/Berat Gedung Kantor & - \\
\hline & & $\begin{array}{l}\text { Pelayanan Kesehatan penduduk miskin } \\
\text { dipuskesmas dan jaringannya }\end{array}$ & 6.420 .550 .000 \\
\hline & & Pengadaan sarana dan prasarana puskesmas & 41.154 .200 .000 \\
\hline \multirow[t]{3}{*}{13} & Budpar & Pengembangan Sarana Prasarana Situs Pati Ayam & - \\
\hline & & $\begin{array}{l}\text { Peningkatan Pengelolaan UPTD Obyek Wisata } \\
\text { Colo }\end{array}$ & - \\
\hline & & JUMLAH & 157.901.647.000 \\
\hline
\end{tabular}

Peraturan Bupati Kudus No 7/2018 tentang penetapan alokasi dana bagi hasil cukai hasil tembakau di kabupaten Kudus tahun 20118 jika dijabarkan akan dapat diketahui beberapa langkah yang dapat dilakukan oleh pemerintah daerah terkait dengan penyerapan kegiatan yang dilakukan sebagai pengaplikasian dari peggunaan DBHCHT, dengan penjabaranya sebagai berikut: 
Administrative Law \& Governance Journal. Volume 3 Issue 1, March 2020 ISSN. 2621-2781 Online

1. Peningkatan Kualitas Bahan Baku, dapat dilakukan melalui berberapa kegiatan yang betujuan untuk menghasilkan bahan baku (tembakau) yang berkualitas, kegiatan tersebut diantaranya:
a. Standarisasi kualitas bahan baku
b. Bahan baku dengan kadar nikotin rendah
c. Sarana laboratorium uji dan metode pengujian
d. Penanganan panen dan pasca panen bahan baku
e. Kelembagaan kelompok tani bahan baku industri HT

2. Pembinaan Industri, dengan tujuan yang akan dicapai berupa teridentifikasinya sarana dan prasarana produksi serta distribusi rokok, yaitu:
a. Pendataan mesin peralatan industri
b. Penerapan HAKI
c. Pembentukan kawasan industri HT
d. Pemetaan industri HT
e. Kemitraan UKM \& UB dlm pengadaan bahan baku
f. Penguatan Kelembagaan asosiasi IHT
g. Penerapan GMP

3. Pembinaan Lingkungan Sosial, dalam hal pembinaan lingkungan sosial dapat dibagi kedalam 6 kegiatan yaitu:

a. Kemampuan \& ketrampilan kerja masyarakat

b. Manajemen limbah industri HT $\rightarrow$ AMDAL

c. Kawasan tanpa asap rokok \& tempat khusus merokok

d. Peningkatan derajat kesehatan masyarakat dng penyediaan fasilitas perawatan kesehatan akibat dampak rokok

e. penguatan sarana dan prasarana kelembagaan pelatihan bagi tenaga kerja industri hasil tembakau

f. Penguatan ekonomi masyarakat di lingkungan industri HT dalam rangka pengentasan kemiskinan, mengurangi pengangguran, mendorong pertumbuhan ekonomi daerah, dilaksanakan antara lain melalui bantuan permodalan dan sarana produksi

Dari ke-6 (enam) kegiatan tersebut tujuan yang ingin dicapai mencangkup 4 (empat) sektor yaitu:

a) Lingkungan yaitu Mencegah pencemaran/perusakan lingkungan 
b) Tenaga Kerja dengan harapan adanya Alih Profesi Petani Tembakau dan Tenaga Kerja IHT

c) Kesehatan berupa Pembentukan KTR serta Rehabiltasi dan Perawatan akibat dampak rokok (tindakan kuratif), dan yang terakhir adalah dalam bidang

d) Perekonomian Masyarakat dalam hal ini tujuan yang ingin dicapai berupa Pengentasan kemiskinan, Mengurangi pengangguran, Mendorong pertumbuhan ekonomi daerah.

4. Sosialisasi Cukai yaitu dengan menyampaikan ketentuan bidang cukai kepada masyarakat baik secara insidentil maupun periode waktu tertentu, sehingga Kepatuhan Masyarakat terhadap aturan Cukai dan Optimalisasi Penerimaan negara.

5. Pemberantasan Cukai Ilegal dalam kasus pemberantasan cukai illegal pemerintah memiliki tujuan berupa Tersedianya Informasi pelanggaran ketentuan terkait pita cukai. Oleh karena itu dibutuhkan beberapa langkah yang harus ditempuh oleh pemerintah yaitu: a). pengumpulan informasi hasil tembakau yang dilekati pita cukai palsu di peredaran atau tempat penjualan eceran, dan b). pengumpulan informasi hasil tembakau yang tidak dilekati pita cukai di peredaran atau tempat penjualan eceran.

\section{Simpulan}

Kebijakan pengaturan (formulasi) tentang pengentasan kemiskinan melalui pengelolaan DBHCHT pada masing-masing daerah berbeda-beda. Hal ini sesuai dengan adanya Undang-Undang Nomor 9 Tahun 2015 tentang Pemerintahan Daerah (perubahan kedua UU No. 23 tahun 2014), UU Cukai dan PMK. Selain itu dengan pengaturan alokasi penggunaan dana DBHCHT yang cukup luwes sehingga menyebabkan pengelolaan DBHCHT lebih maksimal karena cukup intensif untuk melibatkan seluruh stakeholders dalam pengentasan kemiskinan meskipun tetap mengandalkan bagaimana kiprah SKPDSKPD seerta masyarakat dan swasta untuk secara aktif menanggulangi kemiskinan.

\section{E. Daftar Pustaka}

Alwasilah, Chedar, Pokoknya Kualitatif: Dasar-dasar Merancang dan Melakukan Penelitian Kualitatif, Pustaka Jaya, Jakarta, 2002.

Ashshofa, Burhan, Metode Penelitian Hukum, Rineka Karya, Jakarta, 1998, hlm. 20-21 dan Hadari Nawaai dan Mimi Martini, Penelitian Terapan, Gadjah Mada University Press, Yogyakarta, 1996. 
Administrative Law \& Governance Journal. Volume 3 Issue 1, March 2020 ISSN. 2621-2781 Online

Birowo, M.Antonius, Metode Penelitian Komunikasi: Teori dan Aplikasi, Gitanyali, Yogyakarta, 2004.

Black Donald, The Behaviour of Law, Academic Press, New York, 1976.

Bogdan, Robert dan Steven J. Taylor, Kualitatif: Dasar-dasar Penelitian, Usaha Nasional, Surabaya, 1993.

Endraswara, Suwardi, Metode, Teori dan Teknik Penelitian Kebudayaan, Pustaka Widyatama, Yogyakarta, 2006.

Faisal, Sanafiah, Penelitian Kualitatif: Dasar-dasar \& Aplikasinya, Yayasan Asah Asih Asuh, Malang, 1990.

Friedman, Lawrence M., The Legal System, A Social Science Perspective, Russel Sage Foundation, New York, 1975.

Guba, Egon G. dan Y. Vonna S. Lincoln. Handbook of Qualitative Research. Sage Publication. London. 1994.

Indarti, Erlyn, "Selayang Pandang Critical Theory, Critical Legal Theory, dan Critical Legal Studies", Majalah Masalah-Masalah Hukum Fak Hukum Undip, Vol. XXXI No. 3 Juli 2002, Semarang.

Moleong, Lexy, Metodology Penelitian Kualitatif, Remaja Rosdakarya, Bandung, 1996.

Nasution, Metode Penelitian Naturalistik Kualitatif, Tarsito, Bandung, 1992.

Peraturan Bupati Kudus No. 7 Tahun 2018 tentang Alokasi Dana Bagi Hasil Cukai Hasil Tembakau Bagian Pemerintah Provinsi Jawa Tengah Dan Pemerintah Kabupaten Kudus Tahun Anggaran 2018

Peraturan Gubernur Jawa Tengah No 7 Tahun 2018 tentang Alokasi Dana Bagi Hasil Cukai Hasil Tembakau Bagian Pemerintah Provinsi Jawa Tengah Dan Pemerintah Kabupaten/Kota Di Jawa Tengah Tahun Anggaran 2018.

Peraturan Menteri Keuangan Nomor 28/PMK.07/2016 tentang Penggunaan, Pemantauan Dan Evaluasi Dana Bagi Hasil Cukai Hasil Tembakau.

Rahardjo, Satjipto, "Memikirkan Hubungan Hukum dan Kemiskinan”, Gema Keadilan, No.1 Tahun ke 15;1991.

Soemitro, Ronny H, Permasalahan Hukum di Dalam Masyarakat, (Bandunng : Alumni,1984)

Soemitro, Ronny H, Perspektif Sosial Dalam Pemahaman Masalah-Masalah Hukum, (Semarang, Agung Press, 1989).

Soemitro, Ronny H, Studi Hukum dan Kemiskinan, (Semarang : Tugu Muda, 1989)

Soemitro, Ronny H, Studi Hukum dan Masyarakat, (Bandung, Alumni, 1985).

Sukirno, Sadono, Ekonomi Pembangunan, (Jakarta, Bima Grafika, 1985).

Administrative Law \& Governance Journal. Volume 3 Issue 1, March 2020 
Administrative Law \& Governance Journal. Volume 3 Issue 1, March 2020 ISSN. 2621-2781 Online

Suteki dan Galang T, Metodologi Penelitian Hukum, Raja Grafindo, Jogjakarta, 2018

Tamanaha Brian Z., A General Jurisprudence of Law and Society, Oxford University Press, New York, 2006.

Undang-Undang Dasar NRI Tahun 1945

UU No. 39 Tahun 2007 Tentang Cukai

Warassih, Esmi, "Peranan Hukum dan Fungsi-fumngsinya", Masalah-masalah Hukum, No.5 -19 . 